\title{
DIGITAL RESOURCES IN FINANCIAL EDUCATION: PREMISES FOR IMPLEMENTATION IN PRIMARY EDUCATION
}

\author{
Lidia Sabău*, ORCID ID: 0000-0002-2858-7232 \\ "ION CREANGĂ” State Pedagogical University of Chişinău, PhD School „Education Science”, \\ Chişinău city, lon Creangă 1 street, MD-2069 \\ *Corresponding author: Lidia Sabău, sabaulidia05@gmail.com
}

Received: 12.06 .2021

Accepted: 01.23.2022

\begin{abstract}
The digital resources available online provide quality teaching material so that students become familiar in a pleasant, simple, fun and playful way at the same time with elements of economic culture, so that they can easily enter the exciting world of money. From asking for money to making money is a distance that can be covered if certain basic, elementary information is acquired, which leads to certain financial skills that result in certain financial behaviors necessary in the attitude of tomorrow's adult - today's student. As the online environment is very accessible to most people, we consider that spending time in virtual learning new things, assimilating some notions in the financial field is a method available to anyone to inform themselves so as to avoid financially unpleasant situations in time, such as "loans", "card overdrafts", "mortgages", "guarantees", etc., especially when these are not necessarily necessary. The proposed study describes the current situation of the subject taught in the traditional school, analyzes the financial skills of students in contrast to the financial skills of students who do not study this subject. The research problem is related to the inability of students to intelligently manage a sum of money due to poor and insufficient training in the use of useful digital resources that can train their early financial skills.
\end{abstract}

Keywords: digital education; digital resources; financial education; new education; open educational resources.

Rezumat. Resursele digitale disponibile online oferă material didactic de calitate, astfel încât elevii să se familiarizeze într-un mod plăcut, simplu, distractiv și ludic, concomitent cu elemente de cultură economică, astfel încât să poată intra cu ușurință în lumea incitantă a banilor. De la a cere bani până la a face bani este o distanță care poate fi parcursă dacă se dobândesc anumite informații de bază, elementare, ceea ce duce la anumite abilități financiare care au ca rezultat anumite comportamente financiare necesare în atitudinea adultului de mâine - studentul de azi. Întrucât mediul online este foarte accesibil pentru majoritatea oamenilor, considerăm că petrecerea timpului în virtual învățând lucruri noi, asimilarea unor noțiuni din domeniul financiar este o metodă la îndemâna oricui de a se informa astfel încât să evite în timp situații neplăcute din punct de vedere financiar, precum „împrumuturi”, „descoperi de cont de card”, „ipoteci”, „garanții” etc., mai ales când acestea 
nu sunt neapărat necesare. Studiul propus descrie situația actuală a disciplinei predate în școala tradițională, analizează abilitățile financiare ale studenților în contrast cu abilitățile financiare ale elevilor care nu studiază această materie. Problema de cercetare ține de incapacitatea studenților de a gestiona în mod inteligent o sumă de bani din cauza pregătirii slabe și insuficiente în utilizarea resurselor digitale utile care le pot forma abilități financiare timpurii.

Cuvinte cheie: educație digitală; resurse digitale; educație financiară; educație nouă; resurse educaționale deschise.

\section{Introduction}

Education, according to the dictionary, presupposes "a fundamental social phenomenon of transmitting the life experience of adult generations and culture to generations of children and young people", but it also means the formation of the individual in a person capable of thinking and carrying out actions of a certain culture. This phenomenon resides "in a set of methods, measures that are applied in a systematic, organized way, in order to form and develop intellectual, moral, physical characteristics of individuals" [1]. In the case of our research, the segment we are referring to considers the financial education of the little ones, more precisely, of the young school age students.

Studies in the field specify that around the age of 9, the child begins to create his own universe through the prism of what he knows or can learn about money. It is the age when the general perception changes, especially the personal perspective.

Hermann Koepke develops a true theory around the age of nine of the child, a period when very interesting transformations take place in human development, both from an anthropological / biological point of view, but also from a psychological point of view. The thinking of the nine-year-old child reaches the stage of asking questions, of problematizing certain situations, but also of interpreting in a personal way some aspects of real life. For this reason, of the turning point from the age of 9 , "teaching is not allowed to contain anything strictly delimited, as it is never allowed to give the child ready-made representations, which have the ability to transform" [2], because the child is able to act in such a way as to be always an active learning, in constant growth with his own development.

Private providers of financial education are directly interested in the education of children from an economic point of view because the private environment notices more quickly the gaps of individuals, especially when it comes to employment or certain financial responsibilities that employees can not complete or are deficits in this regard [3]. Financial education is required at the level of primary education, but, for the time being, it is provided only in a private setting or in the form of an optional one in the traditional school.

Financial education in primary school means, in fact, the "ABC" in the world of money. At the age of small schooling, information is still assimilated in the form of a game - this is why the way of teaching information in such a serious field, such as economics, must be easy, for the little ones, but also adapted to the age of the little ones students, as well as their level of intellectual development.

If at the preschool and primary level - from kindergarten to the second grade, we are talking about the cycle of fundamental acquisitions, when students prepare for the specifics of schooling, with the acquisition of basic elements (reading, writing, counting), here at the next level - from the third grade to the sixth grade, it is about the developmental cycle, when the student's thinking is similar to that of the adult and becomes abstract, operating with 
abstract notions, but can even develop theories about the world [4]. The student is characterized by curiosity and is able to solve a mental problem - according to Piaget, this is the highest form of thinking, and from this age the student can expand his knowledge, without being hindered by egocentrism or other such restrictions [5].

Hence the interest in implementing financial education starting at least with the third grade: both due to the psychological development of the 9-year-old child and the transition of students to another stage of development in their own educational training - they begin to express themselves correctly in various communication contexts, develops the ability to communicate using specialized languages, develops autonomous thinking, as well as the ability to integrate into the social environment.

The study proposed by us is descriptive in nature as it describes the current situation of this subject taught in the traditional school, as well as comparative in nature, as it exposes the financial skills of students studying this discipline in contrast to the less developed financial skills of students who do not study this subject. It is necessary to introduce this discipline since the period of early schooling, given the multilateral and harmonious development of students through integrated teaching, but also by introducing new education in the school curriculum.

The research problem we intend to analyze is given by the inability of students to intelligently manage a sum of money they have at a given time due to poor and insufficient training in using useful digital resources that can train them early financial skills, even when they don't have real money.

\section{Digital resources in student financial education}

\section{A. New educations in the contemporary school}

Compared to the Industrial Age, characteristic of the period $19^{\text {th }}-20^{\text {th }}$ centuries, when people were trained to become good executors of actions, in the $21^{\text {st }}$ century, in which we carry out our existence, the emphasis is on the formation of a man adaptable to any situation, both socially and professionally. What you learned in school may no longer correspond, as training, to what your employer requires you to do in your new job. Many of the trades have disappeared, others have emerged, and even more trades have replaced the human workforce with high-tech machinery. That is why the emergence of new educations is welcome: they have the role of training modern man in adapting quickly, on the go, to the challenges related to the new.

New educations are, in fact, new objectives of the education of the individual and are generated by the context of the contemporary world. They correspond to social and pedagogical requirements, being both cumulative and integrative, because they involve implications and intersections of several different fields. We mention here some such educations: education related to the environment, education for peace and cooperation, education for participation and democracy, education for population, education for a new international economic order, education for communication and media power, education for change and development, nutrition education, modern economic and domestic education, leisure education. In the Industrial Age of the last century there was no question of the existence of such educations because the purpose of society was different, both in terms of its development and the existence of the individual.

As things have changed relatively quickly due to the amazing advancement of technology, education has also undergone some changes, so that, in fact, everything that happens in terms of training leads to progress. 
In the context of new education, modern economic and domestic education involves the formation of an economic consciousness and conduct for a balanced life, but also an easy integration into social life. "Knowledge and understanding of economic facts in their causal substratum helps to increase the quality of production of goods and thereby improve the quality of life" [3]. At the same time, it is considered the formation of a positive attitude towards goods, the formation of a spirit of cooperation, but also respect for work, as well as the ability to participate directly in the realization of economic projects of society.

New educations are a very current and constantly debated topic, both as a delimitation and as a methodology for implementation. Being educations at the intersection of various fields, they must be maximized. The implications of the new educations lie, in fact, in the formation of the individual on the five dimensions through the process of formationdevelopment of the personality: intellectual, moral, aesthetic, technological and physical.

Financial education is part of the sphere of new education, being part of modern economic and domestic education, as a complete phrase of this education. However, it falls, conceptually speaking, within the social disciplines, although it also has grades in the field of mathematics. We can say that financial education is an integrated discipline because it contains elements from different fields and disciplines: mathematics, economics, romanian language, civic education, personal development, fine arts and even religion. Specifically: when it comes to money, you must know how to count, but also how to express yourself correctly in order to send a certain message (financial or not); the implications of money in social life are known through the different banking products for the population, with emphasis on the differences between the social classes given by wealth and well - being, between those who have and those who do not - hence the contribution of civic education; religious life itself is influenced by money, both by exposing religious writings, parables, and by Christian teachings on acts of charity, volunteering, and good deeds - religious education being especially important when it comes to thinking, speaking and acting Christian; the field of the arts meets the needs of the talented, so as to encourage them to act in the direction of obtaining an income from the native talents - through work, perseverance and discipline.

As it is desired that the individual be multilaterally developed, the appearance of this education - financial education - is also due to the fact that, more recently, a much more special importance is given to the formation of man from all points of view. This individual training of man begins early, but our research considers financial education at the level of primary education - an essential element in the formation of financially sound behaviors.

Through this discipline, learning should not only be a difficult process of assimilating knowledge and information, but a game through which the student becomes familiar with terms that may seem, at first glance, very difficult to understand or assimilated.

\section{B. Digital education in the current historical context}

We believe that the process of training an individual is about three different types of educational resources, with different applicability, but with the same common goal: educating the individual and training him for society, perfectly adapted and prepared for any kind of challenge.

The three types of educational resources are:

- Physical: with reference to any material on physical support (books, magazines, monographs, encyclopedias, CDs, etc.). These resources are easily accessible from libraries or 
bookstores, but require a long time to be selected, viewed, analyzed to have immediate applicability in everyday life. These resources require time and space.

- Human: with reference to the experience of individuals who, through personal example, can influence the training of other people. Learning from another's experience is a learning with a low degree of mastery, especially since the new generation wants to experience, feel, see, live on their own skin certain sensations or emotions that cannot be experienced just by their simple story or verbal presentation.

- Digital: comprise the set of materials located "one click away", so that learning is facilitated by the library on the phone or the electronic device in the immediate vicinity. Online dictionaries, tables, lists with various information, financial resources, applications of all kinds (in the field of health, personal budget, efficient time management, etc.) are in one device: simple, fast, smart, small. These resources save time, space, nerves and money.

Digital education is the education that teaches man to use digital in his personal interest, for his own benefit. It is desirable that the electronic device be a human termination, and not the other way around. For example, the application with a road distance, from point A to point $B$, exposes only the simplest and fastest route to follow, but does not provide details about the landscape that could delight the human soul.

The COVID 19 pandemic period is a beneficial and prolific period for digital creation, experimentation, implementation and results in online learning. Manufacturers of digital materials are the ones who have crafted an effective learning path.

The current context is a context of active and proactive learning: the world of tomorrow belongs to those who are up to date with the news, are informed and always on the verge of action. Information flows at an astonishing speed and connecting to technology as well as real-time communication are paramount so that you are at the heart of the problem that is bothering you.

The European Union is developing in the period 2021-2027 an Action Plan for digital education [7], which aims to reset education and training for the digital age. This action plan provides a long-term strategic vision, addresses the challenges and opportunities created by the pandemic and aims to strengthen cooperation at EU level. To achieve these goals, two priority areas have been established:

1. encouraging the development of a high-performance digital education ecosystem;

2. developing digital skills and competencies relevant to digital transformation.

The second area is of great interest to us because it involves, in addition to training other skills, both "basic digital skills and competences from an early age" and "digital literacy, including to combat misinformation".

Even before the COVID 19 pandemic, digital had a major impact on society, the economy and education. Moreover, today, the times we are going through show us that it is essential to have a system of education and training prepared for the digital age, regardless of the level of education (from preschool to university), the social environment (urban or rural), but also by the educational disciplines (both for the subjects from the common, compulsory trunk, and for the optional subjects - in this case: financial education).

Returning to our subject, Open Educational Resources (OER) are materials for learning, teaching, assessment, research that can be used, adapted and redistributed freely or with minimal restrictions related to copyright. These materials can be accessed freely or for a moderate fee, being on physical media or in digital format: textbooks, books, lesson plans, courses, presentations, questionnaires, games, tests, audio or video resources. 
Digital resources, in general, have the role of providing elements of education in the online environment. They can be accessed from anywhere in the world, from any type of digital device: phone, tablet, computer, laptop. The multitude of variants regarding the access and availability of the supply offers a real support in the instructive-educational process, both for the teachers and for the students. It has now become very easy to access a learning platform, a site with educational materials, an application or even an entire online library to support the training activity, so that everything is at a "click distance".

If we refer to the school field, we could classify digital resources according to the level of addressability, as well as the degree of difficulty that some forms or platforms propose. Some platforms are so well made that the materials are divided on each level of education, but they also have different degrees of complexity. Interestingly, it goes from simple to complex, from small to large, from "micro" to "macro", from easy to difficult, from "beginner" to "advanced" - so that the student is not overwhelmed by complicated learning tasks, but easily adapts to increasingly difficult learning tasks.

A learning program based on the use of new technologies must have certain characteristics, listed by R.C. Clark and R.E. Mayer [5] as follows: to contain a concept with a content relevant to the learning objectives and purposes, to use various teaching methods (exemplification, practical activities) so as to optimally support learning, to use multimedia elements (text, images, animation, films, audio files) as a support to make learning content accessible and to diversify teaching methods, to build knowledge and to develop skills in a direct relationship with the individual objectives of the learner, being a "solution for personalized learning paths".

„Forbes Magazine” provides us with the study conducted by the Orange Foundation, conducted between March 28 and April 8, 2020, in the midst of the COVID 19 pandemic, wanting to identify the digital resources used in the classroom by teachers, so that school courses can continue [4]. According to this study, the most used resources were communication platforms: Zoom, WhatsApp, Google Classroom and Facebook. Subsequently, many teachers participated in Digital Instrument Use (CRED) courses, as well as webinars and distance learning platforms.

\section{Financial education through digital resources}

As we live in an unprecedented historical period, when everything is digitized, including the teaching-learning-assessment process, even financial education is achieved through technology [6]. Students have long been familiar with money, its value, as well as the actions they observe with their own parents: ATM transactions, online payments, online shopping, card payments at the store, etc. Students are no longer absent from financialbanking life: they are aware of elements of finance in a connected way because not only are they very smart, but they also realize certain values, products or services provided for a sum of money [6]. At the same time, students become aware of their power to speculate on their parents' emotions when it comes to desires, not needs.

In Romania, one of the providers of digital resources in youth financial education is Junior Achievement Romania (JA Romania), the largest international organization for economic and entrepreneurship education, which is part of Junior Achievement Europe and Junior Achievement Worldwide, being a non-profit organization, established in 1993, which aims to develop learning by doing and project based programs. These courses are attended annually by over 200,000 pupils and students from over 1700 educational institutions in 
Romania and are conducted in partnership with the Ministry of Education, educational institutions and the business community [6]. Globally, the programs are followed in 40 countries in Europe and over 100 worldwide. The purpose of this organization is "to inspire and prepare the young generation to succeed in life, by encouraging initiative, professionalism and the development of skills essential for personal and professional life."

Another provider of digital financial education materials is the Association for Promoting Performance in Education, which began in 2013 [7]. This association provides primary school students and their teachers with textbooks, workbooks, and a learning platform, where there is the entire proposed financial program, in digital format, so that it can be accessed by anyone and from anywhere, anytime. Against the background of the COVID 19 pandemic, the material resources were digitized and thus made the access to quality, professional materials, made by professionals, accessible to all those involved in the project. It is hoped that in the near future to implement an accredited course so as to train as many teachers as possible to teach financial education to children - from primary education and even pre-primary education.

All digital financial materials provided are made to high standards, regardless of the educational provider [8]. It is true that financial education is desired in primary school, but the legislative framework, as well as the traditional education system, which sometimes seems frozen, only facilitates this type of education in an optional, non-compulsory form, but which is "required" by parents and students. Everyone knows money, everyone uses money in different aspects of their daily lives, from a very young age - when the child asks for something that costs money. Everyone likes money, everyone wants money - as much as possible and as soon as possible, so in conclusion, how nice and useful it would be if they learned about money at school [9]. The program of the optional financial education contains basic elements of the economic area, the students getting acquainted with introductory notions.

The digital resources offered by the www.investory.app application, for example, train students with more concrete and practical notions. Being a phone or tablet application, through this game children learn about "barter", "investment", "profit", "interest", "credit", "ATM", "card" etc. The big advantage is that it does not operate with real money, so no one loses anything and is not illegal with the virtual financial actions they do in the game.

The site www.twinkl.ro is a site that offers a wide range of teaching materials. The educational materials provided are from all disciplines and are presented in several languages, thus adaptable in several countries. The financial education factsheets on this site are very interesting and useful.

From the point of view of materials in the field of financial education for primary school children, we tried to structure the offer of suppliers, so as to create a possible choice for those who want more information in this field:

1. Junior Achievement Romania, www.jaromania.org, it was founded in 1993; it is the largest international organization for economic and entrepreneurship education -activities by learning by doing and project-based, available in school and online -materials on physical support -addressability: 6 - 19 years -year of debut in financial education in primary education: school year 2012 - 2013

2. Association for the Promotion of Performance in Education, www.appe.ro, initially started through a partnership between MENCS and BNR 
-textbooks for everyone in primary school

-auxiliary notebooks for students

-teacher guide $+C D$

-SchoolMate learning platform

-addressability: 6 - 19 years

-year of debut in financial education in primary education: $2013-2014$

3. www.investory.app, use game-based learning, by solving tasks with applicability in real life

-video game through application installed on mobile or tablet

-addressability: 7 - 10 years

-year of debut in financial education in primary education: 2019

4. www.twinkl.ro, currently provides more than 525,000 digital educational resources worldwide in several international languages

-educational resource platform for all disciplines and levels of education

-addressability: 3 - 12 years

-year of debut in financial education in primary education: 2010

What we have set out in the table above are just a few resources from the range of digital resource providers in financial education, but, we believe, they are the most important actors in this stage of financial education in the primary cycle.

In the research developed on the subject of digital resources in the financial education of primary school students we will address several online sources, we will observe their concrete applicability and we will try to develop a model applicable to children, so that their training from an economic point of view is a serious process, carried out early, even if the information is assimilated through play and practice [10].

\section{Conclusions}

Financial education through digital resources involves the implementation (introduction and application) of those resources in technology that facilitate the learning of elements in the economic field. Within this discipline, didactic games, role-playing games can be made, financial operations adapted to the level of young school students can be mimicked - didactic activities that facilitate learning. The didactic game familiarizes students with the world of money and through this method they acquire financial knowledge, so that they will be better prepared to face reality - that is, when they will operate with real money.

The impact of digital resources in financial education is especially important because students assimilate some abstract notions through play and in a way that is very accessible and very much appreciated by them - digital devices. Digital resources make it easier for students to enter the exciting world of money, so that, knowing in advance the mechanisms of how money works in society, they will be able later, as an adult, to make the right decisions and have a relationship healthy with their own finances.

In the knowledge society, when so much emphasis is placed on what is done with what is known (savoir faire), in a world where the training of the individual becomes multidimensional, training in finance is of major importance. This training can be achieved through digital resources starting at an early age, from childhood, at the level of primary education, when the child becomes more aware of the surrounding reality and begins to understand the phenomena around him, regardless of their nature. This is also the theme of our research, so as to demonstrate that financial education through digital resources is a way to train the man of tomorrow - prepared not only theoretically, but also through practical- 
applied activities, so that when it will be put in the face of a certain situation, everyone should be able to behave correctly financially in relation to personal and social aspects.

Acknowledgments. This paper work was presented at the "International Conference on Electronics Communications and Computing, IC ECCO”, 21-22 October, 2021, Chisinau, TUM.

\section{References}

1. William B. Walstad, Ken Rebeck, Richard A. MacDONALD. The Effects of Financial Education on the Financial Knowledge of High School Students. The Journal of Cons. Affairs 2010, Volume44, Issue 2, pp. $336-357$.

2. Koepke H. The child at the age of nine, Triade Publishing House, 2001, Cluj-Napoca, ISBN: 973-9196-95-0, p. 81.

3. https://www.creeaza.com/didactica/didactica-pedagogie/Noile-educatii351.php (accessed on 16.08.2021).

4. https://www.forbes.ro/studiu-digitaliada-care-sunt-resurse-digitale-pe-care-le-folosesc-profesorii-162110 (accessed on 10.08.2021).

5. www.jaromania.org (accessed on 10.08.2021).

6. Clark R.C., Mayer R.E. E-learning and the Science of Instruction, San Francisco, 2002, p. 322, ISBN 0-78796051-9.

7. https://ec.europa.eu/education/education-in-the-eu/digital-education-action-plan_en (accessed on 09.08.2021).

8. Johnson A. M., Jacovina M. E., Russell D. E., \& Soto C. M. (2016). Challenges and solutions when using technologies in the classroom. In S. A. Crossley \& D. S. McNamara (Eds.) Adaptive educational technologies for literacy instruction (pp. 13 - 29). 2016, New York: Taylor \& Francis.

9. OECD. The Funding of School Education: Connecting Resources and Learning. 2017) OECD Publishing, Paris. http://dx.doi.org/10.1787/9789264276147-en

10. Tarcísio Pedro Da Silva, Cristian Baú Dal Magromarcello, Christiano Gorlawilson, Toshiro Nakamura. Financial education level of high school students and its economic reflections. Education, Research \& Academic Production • Rev. Adm. (São Paulo) 52 (3) • 2017 • https://doi.org/10.1016/j.rausp.2016.12.010 